\title{
Trwałość zmęczeniowa bimetalu cyrkon-stal w aspekcie charakterystyki złącza
}

\author{
Fatigue life Zr-CS bimetal \\ in terms of the characteristics of the joint
}

\section{Streszczenie}

W pracy opisano rozwój pęknięć zmęczeniowych w układach platerów cyrkon-stal spajanych metodą zgrzewania wybuchowego. Próbki o przekroju poprzecznym prostokątnym, charakteryzujące się zróżnicowanym udziałem warstwy przetopionej, poddano wahadłowemu zginaniu oraz wykonano pomiary twardości w obszarze złącza. W odkształconych próbkach zaobserwowano wzrost pęknięć zmęczeniowych równolegle do przyłożonego obciążenia. Inicjacja pęknięć występowała w cyrkonie.

Słowa kluczowe: zgrzewanie wybuchowe, zginanie, zmęczenie, twardość

\begin{abstract}
The paper describes a fatigue crack development in zirconium-steel sheets joined by the explosive welding technology. The clad specimens of rectangular cross-section and with different quantity of melted areas were subjected to oscillatory bending. The strain hardening across the interface was analysed by microhardness measurements. In the specimens, the fatigue crack growth parallel to the applied loading was observed. The crack initiation occurred always in the zirconium plate.
\end{abstract}

Keywords: explosive welding, bending, fatigue, hardness

\section{Wstęp}

Do wytwarzania układów warstwowych w wielu przypadkach stosowana jest technologia zgrzewania wybuchowego [1]. Pozwala ona uzyskiwać trwałe, ciągłe i jakościowo dobre połączenie dwóch lub kilku materiałów, często o bardzo różnych własnościach mechanicznych. Uzyskanie takiego połączenia wymaga szczególnie starannego doboru parametrów procesu zgrzewania wybuchowego, tj. energii wybuchu, prędkości detonacji oraz odległości pomiędzy łączonymi blachami. Nieodpowiedni dobór tych parametrów, np. poniżej wartości granicznych, może doprowadzić do powstania nieciągłości lub całkowitego braku połączenia. Natomiast przekroczenie wartości krytycznych powoduje nadtapianie powierzchni łączonych blach i w efekcie tworzenie się niekorzystnych, z punktu widzenia jakości połączenia, obszarów przetopionych o dużej twardości i kruchości [2,3]. Badania zmęczeniowe pozwalają na ocenę trwałości uzyskanych układów warstwowych, a analiza propagacji pęknięć zmęczeniowych wskazuje miejsca najbardziej podatne na uszkodzenia oraz charakter ich przebiegu w łączonych materiałach.

Celem prezentowanej pracy jest badanie trwałości zmęczeniowej z uwzględnieniem pęknięć zmęczeniowych przy zginaniu wahadłowym bimetalu cyrkon-stal powstałego przy różnych parametrach zgrzewania wybuchowego.

\section{Metodyka badań}

Układy platerów wykonano technologią zgrzewania wybuchowego, jako płyty próbne o wymiarach 300x500 mm. Płytą podstawową jest blacha ze stali niestopowej do pracy w podwyższonych temperaturach $w$ gatunku P355NL2, natomiast blacha nakładana to czysty technicznie cyrkon w gatunku Zr 700. Skład chemiczny, według atestu producenta podano $\mathrm{w}$ tablicy I.

Proces zgrzewania prowadzono w układzie płyt równoległych, zmieniając dla poszczególnych układów prędkość detonacji (pr. 1: v1 $=3000 \mathrm{~m} / \mathrm{s}$, pr. 2: v2 $=2800 \mathrm{~m} / \mathrm{s}$, pr. 3 : $\mathrm{v} 3=2200 \mathrm{~m} / \mathrm{s}) \mathrm{z}$ jednoczesnym zachowaniem stałej początkowej odległości pomiędzy powierzchniami łączonych blach $(\mathrm{h}=6 \mathrm{~mm})$.

Po platerowaniu wszystkie materiały poddano badaniom ultradźwiękowym, na całej powierzchni, w celu określenia ciągłości złącza. Materiał do dalszych badań pobrano z obszarów bez oznak nieciągłości, na przekroju prostopadłym do powierzchni blachy oraz równolegle do kierunku przemieszczania się fali wybuchu.

Badania własności mechanicznych po procesie spajania tj. próby ścinania (RS,), odrywania (RO) oraz rozciągania $(\mathrm{Rm})$, przeprowadzono na maszynie wytrzymałościowej WPM ZD20 oraz Instron 6025.

Zgłady do badań metalograficznych wykonano na prze-

Dr inż. Mariusz Prażmowski; dr hab. inż. Dariusz Rozumek - Politechnika Opolska; prof. dr hab. inż. Henryk Paul - Instytut Metalurgii i Inżynierii Materiałowej PAN w Krakowie

Autor korespondencyjny/Corresponding author: m.prazmowski@po.opole.pl 
Tablica I. Skład chemiczny łączonych blach, wg. atestu dostawcy [\%wag.]

Table I. The chemical composition of joined metal sheets, as per the supplier's certificate [in wt\%]

\begin{tabular}{|l|c|c|c|c|c|c|c|c|c|c|c|c|c|c|}
\hline Materiał & $\mathrm{C}$ & $\mathrm{Mn}$ & $\mathrm{Si}$ & $\mathrm{P}$ & $\mathrm{S}$ & $\mathrm{Ni}$ & $\mathrm{Cr}$ & $\mathrm{H}$ & $\mathrm{N}$ & $\mathrm{Al}$ & $\mathrm{Mo}$ & $\mathrm{O}$ & $\mathrm{Nb}$ & $\mathrm{Fe}$ \\
\hline Zr 700 & $<0,002$ & - & - & - & - & - & 0.05 & $<0,0003$ & $<0,002$ & - & - & 0,05 & - & 0,05 \\
\hline P355NL2 & 0.170 & 1,130 & 0.345 & 0.008 & 0.001 & 0,285 & 0,150 & - & 0,004 & 0,045 & 0,035 & - & 0,019 & Reszta \\
\hline
\end{tabular}

kroju prostopadłym do powierzchni blachy oraz równolegle do kierunku przemieszczania się fali detonacji. Badania metalograficzne przeprowadzono wykorzystując mikroskop optyczny OLYMPUS IX 70 współpracujący z komputerowym analizatorem obrazu LECO IA 32. Prowadzone analizy pozwoliły na określenie charakterystyki złącza oraz ilościowego udziału warstwy przetopień w poszczególnych próbkach w oparciu o pomiar podstawowych parametrów granicy połączenia.

Wymiary i kształt próbek do badań zmęczeniowych, przedstawiono na rysunku 1. Próbki wycięto z blachy równolegle do kierunku detonacji i przygotowano zgodnie z normą ASTM D 3165-95. Badano próbki, w których stosunek netto wysokości cyrkonu do stali wynosił h1 : h2 = $1: 2,5$. Właściwości statyczne badanych materiałów przed połączeniem, na podstawie atestu producenta przedstawiono w tablicy II.

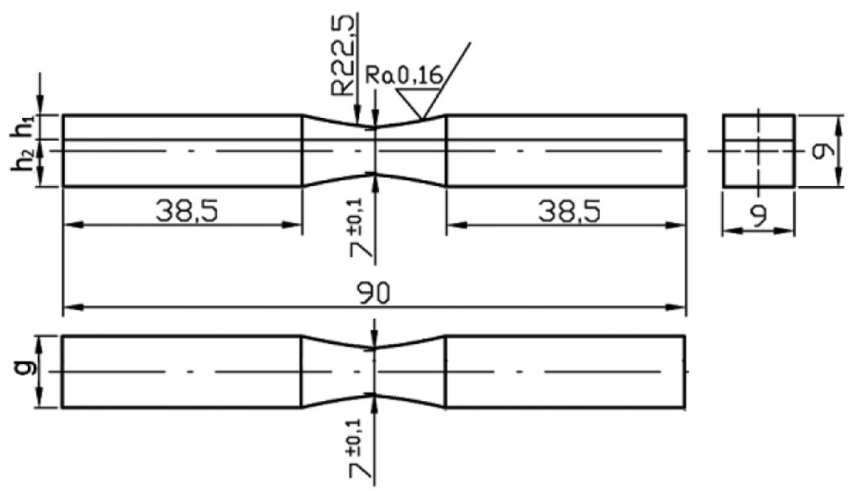

Rys. 1. Kształt i rozmiary próbki, wymiary $\mathrm{w} \mathrm{mm}$

Fig. 1. Shape and dimensions of specimen, dimensions in $\mathrm{mm}$

Tablica II. Własności mechaniczne badanych materiałów przed połączeniem

Table II. Mechanical properties of materials before cladding

\begin{tabular}{|l|c|c|c|c|}
\hline Materiał & $\mathrm{R}_{\mathrm{e}}, \mathrm{MPa}$ & $\mathrm{R}_{\mathrm{m}}, \mathrm{MPa}$ & $\mathrm{E}, \mathrm{GPa}$ & $\mathrm{A}_{5} \%$ \\
\hline Zr 700 & 143 & 300 & 100 & 31 \\
\hline P355NL2 & 402 & 511 & 210 & 27 \\
\hline
\end{tabular}

Badania rozwoju pęknięć zmęczeniowych prowadzono na maszynie zmęczeniowej MZGS-100 umożliwiającej realizację przebiegów zginania [4] przy obciążeniu z kontrolowaną siłą (amplitudą momentu) i częstotliwością obciążenia 28,4 Hz. Badania zmęczeniowe prowadzono przy współczynniku asymetrii cyklu $\mathrm{R}=-1$ i stałej amplitudzie momentu $M a=14,2 \mathrm{~N} \cdot \mathrm{m}$. Teoretyczny współczynnik kształtu karbu w próbce wyznaczono zgodnie z równaniem podanym w pracy [5], który przy zginaniu wynosił $\alpha_{k}=1,045$. Rozwój pęknięć obserwowano na powierzchniach bocznych próbek za pomocą mikroskopu optycznego, bezpośrednio na maszynie zmęczeniowej. Przyrosty pęknięć zmęczeniowych mierzono za pomocą mikrometru umieszczonego w mikroskopie o powiększeniu $25 x$ z dokładnością 0,01 mm, notując jednocześnie bieżącą liczbę cykli obciążenia N. Pomiar długości pęknięcia mierzono, jako przyrost tej długości na przekroju poprzecznym.

\section{Wyniki badań i ich analiza}

\section{Obserwacje strukturalne}

Granicę połączenia scharakteryzowano w oparciu o pomiar długości linii złącza (L), wysokości (H) i długości (n) fali oraz pola powierzchni przetopień (P) (rys. 2). W oparciu o średnie wartości otrzymanych wyników wyznaczono za pomocą równania 1 współczynnik RGP określający równoważną ilość przetopień (tzn. udział stref przetopień w złączu). Otrzymane wyniki dla poszczególnych próbek przedstawiono na rysunku 3.

$$
R G P=\frac{\sum_{i=1}^{n} P_{i}}{L}
$$

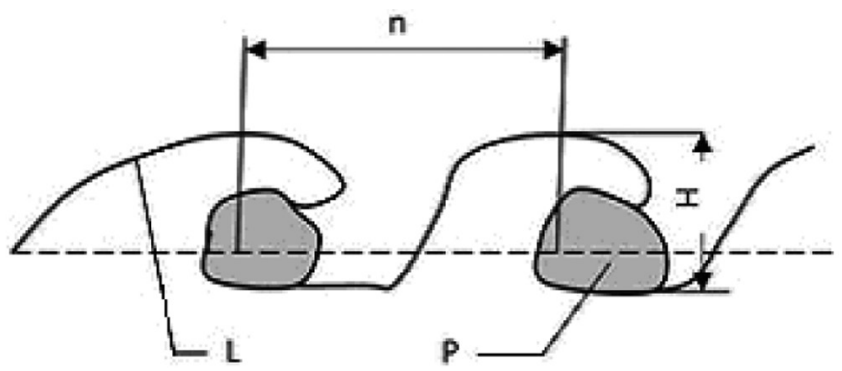

Rys. 2. Schemat fali powstałej w wyniku zgrzewania wybuchowego, gdzie: $\mathrm{n}$ - długość fali, $\mathrm{H}$ - wysokość fali, $\mathrm{P}$ - obszary przetopione, $\mathrm{L}$ - linia złącza

Fig. 2. Schematic presentation of the wave formed as the result of explosion welding, where: $n$ - wave length, $\mathrm{H}$ - wave height $\mathrm{P}$ melted area, $L$ - interface line

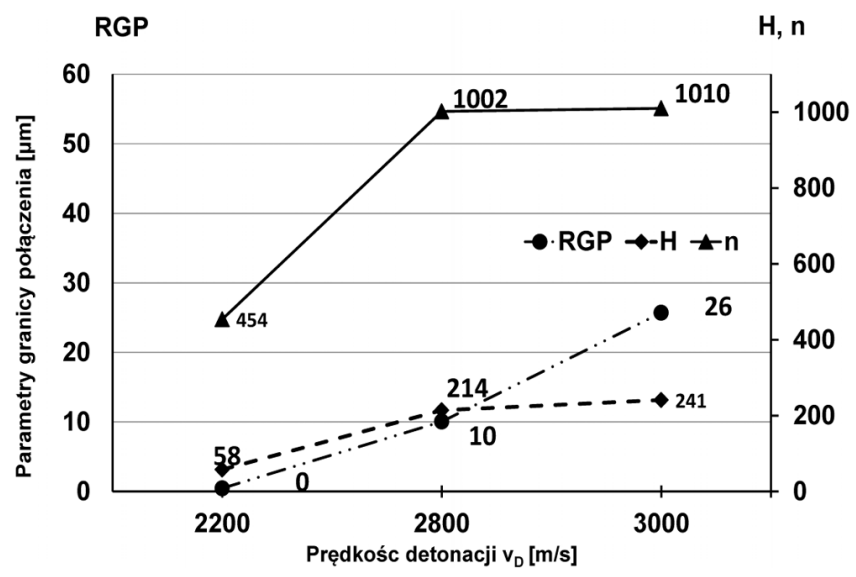

Rys. 3. Parametry granicy połączenia dla próbek o różnej prędkości detonacji

Fig. 3. Parameters of the interface for samples with varying velocity of detonation

Zastosowanie najmniejszej prędkości detonacji (próbka 3) spowodowało, uformowanie granicy połączenia charakteryzującego się regularną falą o najmniejszej (spośród analizowanych przypadków) amplitudzie (rys. 4c). Przy tej prędkości zaobserwowano nieznaczną ilość warstwy przetopionej ( $R G P$ na poziomie $0,5 \mu \mathrm{m})$. Wzrost prędkości deto- 
nacji o $27 \%$ i $35 \%$, w obu analizowanych przypadkach, spowodował ponad 2-krotny wzrost długości fali $(n)$, natomiast wysokość $(H)$ wzrosła prawie 4-krotnie. Zwiększenie prędkości detonacji miało znaczący wpływ na udział warstwy przetopionej w złączu $(R G P)$. W przypadku próbki 2 parametr ten wzrósł do wartości $10 \mu \mathrm{m}$; z punktu widzenia jakości połączenia wartość ta jest przyjęta za graniczną. Dalsze zwiększenie prędkości detonacji (próbka 1, rys. 4a), spowodowało gwałtowne zwiększenie udziału obszarów przetopionych do nieakceptowalnego poziomu $\mathrm{RGP}=26 \mu \mathrm{m}$.

a)

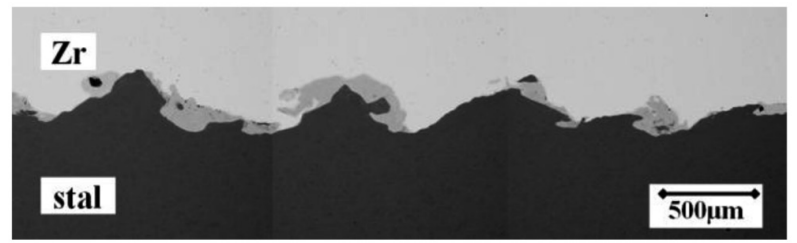

b)

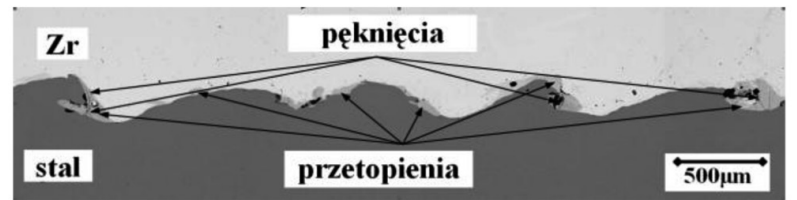

c)

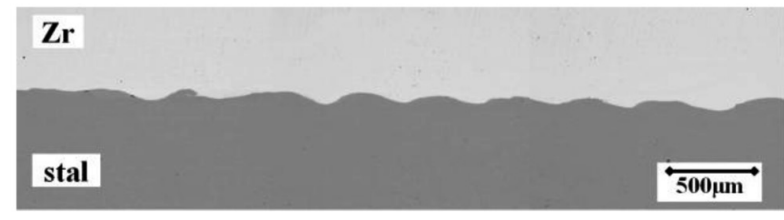

Rys. 4. Mikrostruktura złącza cyrkon-stal: a) i b) z warstwą przetopioną, c) bez warstwy przetopionej

Fig. 4. Joint microstructure of zirconium-steel: , a) and b) with melted areas, c) without melted areas

\section{Badanie własności mechanicznych w warunkach statycznych}

Przeprowadzone próby wytrzymałościowe, dla materiałów w stanie ,po spojeniu', pozwoliły na ocenę jakości otrzymanego połączenia. Dla wszystkich trzech przypadków przeprowadzono próby rozciągania (dla oceny wytrzymałości na ścinanie), a średnie wartości uzyskanych wyników przedstawiono na rysunku 5. Analizując uzyskane wyniki dla próby ścinania i odrywania można stwierdzić, że wzrost prędkości detonacji, a tym samym wzrost udziału warstwy przetopionej w złączu powodował spadek własności wytrzymałościowych. Efekt ten w mniejszym stopniu jest obserwowany w przypadku próby ścinania, w której dla próbki 3 (bez strefy przetopionej) uzyskano wartość $393 \mathrm{MPa}$, natomiast dla próbki 1, tj. z największym udziałem obszarów

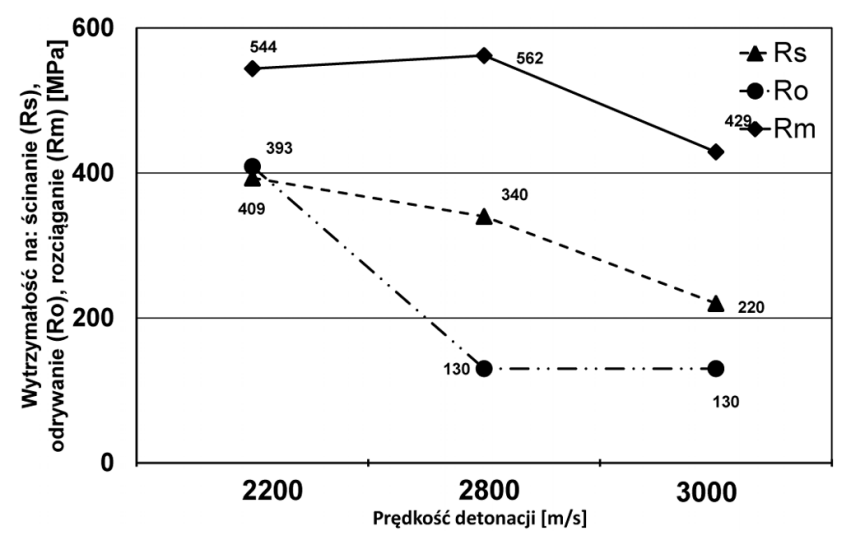

Rys. 5. Własności mechaniczne (wytrzymałość na: ścinanie - $R_{s}$ odrywanie - $R_{0}$, rozciąganie - $R_{m}$ ) plateru

Fig. 5. Mechanical properties (shear strength - $R_{s,}$ peel-off strength - $R_{0}$, ultimate strength $-R_{m}$ ) of the clad przetopionych - $220 \mathrm{MPa}$. Wskazuje to na $20 \%$ spadek wytrzymałości. W przypadku pozostałych dwóch prób, odrywania i rozciągania, również najwyższe wartości zanotowano dla próbki 3, odpowiednio $R_{o}=409 \mathrm{MPa}$ i $R_{m}=544 \mathrm{MPa}$. Dla próbki 1 otrzymano w próbach odrywania $R_{0}=130 \mathrm{MPa}$, tak samo, jak w próbce 2 o dopuszczalnym granicznym udziale przetopień w strefie połączenia, co stanowi ok. $40 \%$ spadek wytrzymałości na odrywanie.

\section{Badanie rozwoju pęknięć zmęczeniowych}

Podczas prowadzenia badań zmęczeniowych przy zginaniu obserwowano rozwój pęknięć w bimetalu cyrkon-stal dla próbek z dużą (pr. 1) i nieznaczną warstwą przetopień (pr. 2) oraz bez warstwy przetopień (pr. 3). Na rysunku 6 przedstawiono przykładowy rozwój pęknięć zmęczeniowych próbek 1 i 2 w funkcji liczby cykli. Próbki badano przy amplitudzie obciążenia $\mathrm{M}_{\mathrm{a}}=14,2 \mathrm{~N} \cdot \mathrm{m}$, a zniszczenie nastąpiło w próbce 1 z dużą warstwą przetopień, po $\mathrm{N}_{\mathrm{f}}=1584000$ cykli, natomiast w próbce 2 z nieznaczną warstwą przetopień, po $N_{f}=1395000$ cykli. Próbki nr 3 miały trwałość $w$ zakresie bardzo wysokiej liczby cykli, nie uzyskano złomu (pękła tylko jedna próbka przy $N_{f}=5982000$ cykli). Inicjację pęknięcia zmęczeniowego obserwowano w próbce 1 po 1510000 cykli, a w próbce 2 po 1342000 cykli, przy długości 0,21 mm (pr. 1) i 0,25 mm (pr. 2). Próbki charakteryzowały się równomiernym wzrostem pęknięć zmęczeniowych po obu stronach powierzchni bocznych.

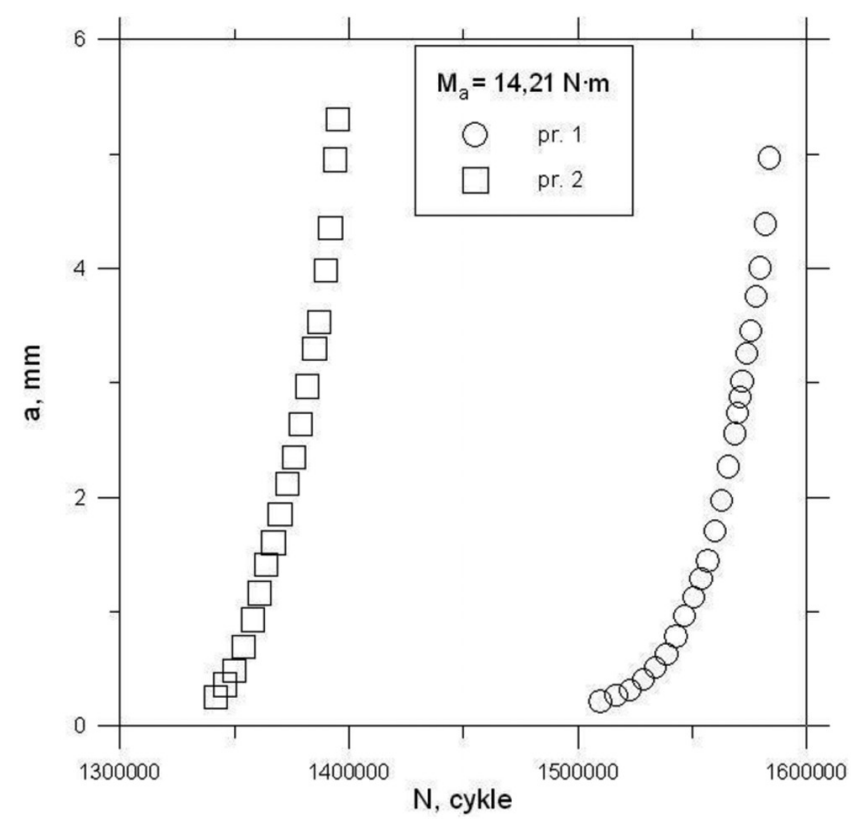

Rys. 6. Długości pęknięć w funkcji liczby cykli

Fig. 6. Cracks length vs. number of cycles

Podczas badań obserwowano inicjację i rozwój pęknięć zmęczeniowych od strony cyrkonu. Pęknięcia pokazane na rys. 7 rozwijały się na płaszczyznach prostopadłych do największych wektora naprężeń normalnych w cyrkonie i po dojściu do złącza, przecinały je przechodząc do stali, w której pęknięcia propagowały podobnie jak w cyrkonie. Przyczynę takiego zachowania pęknięć można tłumaczyć różnym stopniem lokalnego zdefektowania sieci krystalograficznych obu materiałów na granicy złącza w wyniku zderzenia łączonych materiałów oraz różną twardością badanych materiałów. Rozwój pęknięć następuje w miejscach, gdzie na skutek zdefektowania sieci krystalograficznej, zgrzewaniem wybuchowym, wiązania międzyatomowe są najsłabsze. 


\section{Wnioski}

Na podstawie przeprowadzonych badań próbek bimetalu, sformułowano następujące wnioski:

1. Parametry procesu zgrzewania wybuchowego mają kluczowe znaczenie dla charakterystyki uzyskanego połączenia. Wzrost prędkości detonacji sprzyja wzrostowi parametrów połączenia o charakterze falistym (większa amplituda i długość fali), a przede większemu większej ilości stref przetopionych w złączu.

2. Udział warstwy przetopionej w złączu ma znaczący wpływ na statyczne własności wytrzymałościowe bimetalu oraz jego trwałość zmęczeniową.

3. W badanym układzie bimetalowym zaobserwowano rozwój pęknięć na wskroś przekroju poprzecznego próbek, przy czym inicjacja oraz rozwój pęknięć zmęczeniowych przebiegał od strony blachy cyrkonowej.

\section{Literatura}

[1] Crossland B., Explosive welding of metals and its application, Clarendon Press, Oxford, 1982.

[2] Prażmowski M., Paul H.: The effect of stand-off distance on the structure and properties of zirconium - carbon steel bimetal produced by explosion welding, Archives of Metallurgy and Materials, Vol. 57, No. 4, 2012, pp. $1201-1210$

[3] Prażmowski M., Paul H., Rozumek D., Marcisz E., Influence of the microstructure near the interface of the fatigue life of explosively welded carbon steel/Zr clads, Key Engineering Materials, Vols. 592-593, 2014, pp. 704-707.

[4] Rozumek D., Mieszane sposoby pękania zmęczeniowego materiałów konstrukcyjnych, Studia i Monografie, z. 241, Politechnika Opolska, Opole, 2009, s. 152.

[5] Thum A., Petersen C., Swenson O., Verformung, Spannung und Kerbwirkung. VDI, Duesseldorf, 1960. 